\title{
Globalising Security Law for a Globalised Arms Trade
}

\section{Document Version}

Accepted author manuscript

Link to publication record in Manchester Research Explorer

\section{Citation for published version (APA):}

Musa, S. (2017). Globalising Security Law for a Globalised Arms Trade. In THE GLOBAL COMMUNITY: Yearbook of International Law and Jurisprudence Oxford University Press.

\section{Published in:}

THE GLOBAL COMMUNITY

\section{Citing this paper}

Please note that where the full-text provided on Manchester Research Explorer is the Author Accepted Manuscript or Proof version this may differ from the final Published version. If citing, it is advised that you check and use the publisher's definitive version.

\section{General rights}

Copyright and moral rights for the publications made accessible in the Research Explorer are retained by the authors and/or other copyright owners and it is a condition of accessing publications that users recognise and abide by the legal requirements associated with these rights.

\section{Takedown policy}

If you believe that this document breaches copyright please refer to the University of Manchester's Takedown Procedures [http://man.ac.uk/04Y6Bo] or contact uml.scholarlycommunications@manchester.ac.uk providing relevant details, so we can investigate your claim.

\section{OPEN ACCESS}




\section{THE GLOBAL COMMUNITY}

Yearbook of International Law and Jurisprudence

2016

Edited by

Giuliana Ziccardi Capaldo 


\title{
Globalising Security Law for a Globalised Arms Trade
}

\author{
BY SHAVANA MUSA*
}

\begin{abstract}
The constant evolution of the ever-globalising arms trade has posed complex questions as to its regulation. This article attempts to address the question of whether globalising law and regulation of the arms trade is the answer, particularly given the rapid rate at which all aspects of this industry are evolving, its pluralistic character and the increasing authority that diverse involved actors have. It is the case that in the last few years, the global community has managed to agree to the Arms Trade Treaty (ATT). This shows a significant step in the global governance of an inherently global industry. In questioning whether and how global law for the arms trade can be shaped, this article also assesses the eventual ATT provisions and whether they adequately deal with the globalising elements of the arms industry.
\end{abstract}

\section{INTRODUCTION: THE CHANGING NATURE OF THE ARMS TRADE}

Arms exports can be described as a burgeoning part of trade. Whilst indeed they are burgeoning, it is probably more apt to say that they have morphed into a global trade with a character of only sheer might, increasing year by year. ${ }^{1}$ This is so much so that 'in few other domains has globalisation been so extensive, visibly encompassing the global, or conceived in human social and political terms, so (potentially) catastrophic.'2 One need only look at trends of military expenditure to see various complicated factors at play.

\footnotetext{
* Ph.D.; Lecturer in Law at The University of Manchester, UK.

${ }^{1}$ MarkBromley, Paul Holtom, Sam Perlo-Freeman \& PieterD. Wezeman, Recent Trendsin the Arms Trade, SIPRI BACKground PAPer, April 2009; SIPRI, International Arms Transfer, <https://www.sipri.org/research/ armament-and-disarmament/arms-transfers-and-military-spending/international-arms-transfers > .

2 David Held, Anthony McGrew, David Goldblati \& Jonathan Perraton, Global Transformations: Politics, Economics and Culture 87 (1999).
} 
Firstly, findings from analytical studies show the increased spending on arms as a reflection of increased national insecurity. This is one reason that patterns of high amounts of spending appear concentrated in smaller, fragile countries involved in internal wars, symptomatic of the move towards intra-state warfare over the last few decades. ${ }^{3}$ The illicit flow of small arms and light weapons to these countries is particularly problematic and the prevalent availability of weapons has been an enormous factor in over 250 conflicts during the last ten years. A UN Report released in 2015 stated that this had led to a high death rate and astronomical numbers of people displaced. ${ }^{4}$ For example, in Somalia alone, 10,548 deaths were recorded in 2014, an increase of $25 \%$ from the previous year. ${ }^{5}$

There are other more financially inducing motives behind arms exports. The globality of the arms trade is also evident through the endless companies involved in the supply chain process, from suppliers for services and components of arms to even just affiliated partners from diverse markets around the world. Aside from the traditional intergovernmental arms transactions that take place, involved parties often include private entities, making the arms trade even more complex. It is, without a doubt, the embodiment of heterogeneity. Components of military equipment are also no longer wholly produced in one single country, but obtained from across the globe: 'production facilities are set up in new, often developing, countries, brokers and dealers flourish, technology is traded, and arms companies produce their branded weapons in many locations. ${ }^{6}$

More and more countries are extending their defence capabilities and companies such as BAE Systems and Boeing are quite apparently monopolising the defence industry. Even transactions themselves have evolved tremendously. For a start, the proliferation of offset arrangements since the 1970s has allowed for an increase in the number of countries around the world to procure arms. Through a contribution to the industrial development process, this arrangement allows the possibility of reducing cost during the procurement of arms from an international supplier. Other compensatory contributions have included the transfer of technologies or direct investment. The emergence of this practice opened the doors for many developing countries to enter the arms trade. However, recently, there has been a decline in the use of offset arrangements and a more apparent move towards joint ventures. This change has done even more to expand the range of actors involved in the supply chain. ${ }^{7}$ From the 1990s onwards, countries saw the benefits of joint ventures, which included producing and utilising the same defence equipment as allies and, consequently, interoperable weapon systems. One well-known joint venture example is the Joint Strike Fighter that involved nine countries in the manufacturing and operation processes of the product. $^{8}$

One other area that is continuously under fire and shining a torch on the difficulties of regulating the arms trade is the dual-use of weapons and their increasing sophistication. Components for weapon systems are also a large aspect of this type of trade, which are not only used in these systems but in items utilised by ordinary civilians. Products of the

\footnotetext{
${ }^{3}$ International Committee of the Red Cross, Arms Availability and the Situation of Civilians in Armed Conflict: A Study Presented by the ICRC, ICRC Publication ref. 0734 (1999).

${ }^{4}$ United Nations Security Council, Small Arms and Light Weapons, S/2015/289 (2015).

${ }^{5}$ Id., at 5 .

${ }^{6}$ Edmund Cairns, Arms without Borders, Arms without Borders: Why a Globalised Trade Needs Global Control 7 (2006).

7 Jurgen Brauer \& J. Paul Dunne, Arms Trade Offsets and Development, 35 Africanus 14 (2005).

${ }^{8}$ See the F-35 Lightning II official website, <http://www.jsf.mil/index.htm>; Rachel Stohl \& SuzetTe Grillot, The International Arms Trade (2009).
} 
so-called 'dual-use' purpose are often dominating the markets, more so than solely military ones and reflect the globalising economy. Changes in this area have meant that

$[\mathrm{m}]$ any areas of technology that were once the preserve of the military and security services, such as cryptography, now have primarily commercial applications. In addition, the use of standard commercial components is an increasing feature of the arms industry: many components of major weapon systems are commercial off-the-shelf products, produced by manufacturers that would not consider themselves part of the arms industry. The major contractors have become increasingly systems integrators, retaining the characteristics of defense specialized firms. ${ }^{9}$

Furthermore, recent events, particularly in the Middle East, demonstrate the ease in which weapons can involve and affect the ordinary civilian in other more devastating ways. One need only look at the civilian injury and damage that has and still is occurring in Yemen by the Saudi-led coalition. To make matters worse, evidence has brought to light the role of UK weapons in the Saudi-led campaign; the United Kingdom, conversely, is in fact seen as the forerunner in the regulation of the arms trade. ${ }^{10}$ In the same vein, although the United States, Israel, Russia and European countries such as the United Kingdom and Germany are seen to be the 'big players' within the arms trade, new BRICS companies-that is, Brazil, India, China and South Korea-are entering the game, placing the arms trade on a natural course of evolution. Other predicaments facing the industry surround safety, bribery, corruption, environmental and, of course, as in the case of Yemen, the potential humanitarian and human rights violations that could occur if the transfers of arms are not properly regulated.

All of these problems undoubtedly paint a picture of the multi-faceted nature of the arms trade, which in identifying its different dimensions can be coupled with the difficulties surrounding its regulation. Whilst in the past the industry was shrouded in a layer of secrecy, pressure from external forces have called for the instilling of more transparency within relevant processes. This was to expose the realpolitik decision-making that occurred-and still is - in licensing regimes, resulting in the approval of licences that may have unwanted negative consequences for civilians and the wider society. This particular issue will be dealt with in more depth later on in the article.

Of course, regulation is not completely lacking and there is a multifarious array of arms trade regulation within national regimes and the international sphere. US legislation, for one, has been known for its onerous corruption and anti-bribery laws. Even with numerous national and international laws, as well regulatory bodies, arms that have supposedly undergone legal processes still tend to cause conflict and insecurity, going against the core purpose of defence and security. Companies may not always be concerned by these issues, particularly when exporting to a recipient who is making substantial payments, but in fact, these subsequent aftereffects can have a serious impact on a company's reputation and functioning. In this way, it is as equally beneficial for companies, as well as governments to adhere to good arms regulation.

\footnotetext{
9 The Modern Defense Industry: Political, Economic, and Technological Issues (Richard A. Bitzinger ed., 2009); J. Paul Dunne, with the SIPRI Arms Production Program Staff, Developments in the Global Arms Industry from the End of the Cold War to the mid-2000s 16.

${ }^{10}$ Shavana Musa, Has the UK Violated International Laws in Yemen Conflict, available online at <http://blog. policy.manchester.ac.uk/posts/2016/10/has-the-uk-violated-international-laws-in-yemen-conflict/>. Also see the work of CAEC.
} 
With globalisation not intending to shy away anytime soon, there is a growing need for agreed values and approaches to monitoring and data distribution. This is even more desired given the varying — and confusing — rules and regulations in differing legal regimes, all involved in just one transfer. With this fragmentation comes the risk that forum shopping will take place, where those involved in the arms transaction pick the rules that have the most advantages for them. The multitude of regimes also facilitates corruption and underhand tactics and behaviours, which could lead to the diversion of arms to third parties with questionable standards. In order to deal with all these complex and varying problems, in a world that sees the momentum of globalisation increasing rapidly, it becomes imperative to evaluate the current arms trade landscape, along with its accompanying law, to assess whether it sufficiently satisfies the requirements of this context.

This article will therefore attempt to address the question of whether globalising law and regulation on the arms trade is the answer, particularly given the rapid rate at which all aspects of this industry are evolving and the increasing authority that involved actors have. It is the case that in the last few years, the global community has managed to agree to the Arms Trade Treaty (ATT). This shows a significant step in the global governance of an inherently global industry. In setting out a theoretical context on whether and how global law for the arms trade can be shaped, this article will also assess the eventual ATT provisions and whether they adequately deal with the globalising elements of the arms industry. It will finally conclude on the way forward in terms of globalising security law for an everglobalising arms trade.

\section{GLOBAL LAW FOR ARMS CONTROL?}

Whether there is a need for global law, particularly for the arms trade, is a long-asked question. In a world where the role of international courts and organisations are being placed under scrutiny for their capacity to address ever-complex global issues; where the global community is adopting laws that transcend national 'sovereign' boundaries and that are fundamentally applicable to many systems; as well as a general de-territorialisation of the practice of state and non-state actors alike, the question of how we legally contend with globalisation remains pressing.

A single treaty to outline the obligations of parties involved in arms transfers and to regulate as complex an area as the arms trade constitutes one recent development. The global community recently reached a milestone with the Arms Trade Treaty, applying this first hand, and which, rightly so, has been the subject of much debate and discussion. This article will certainly be paying tribute to the treaty as one tiptoe in the marathon of globalising law, as well as dissecting its flaws for precisely the same reason. However, before it delves into the crux of the treaty, the article will discuss the notion of global law, and its normative value, for the arms trade more generally. Given that globalisation has come a long way from merely rearing its head, more so within the arms trade, which has the potential to shake every crevice of our global security, it is important to ask whether global law is the answer and what this would entail.

First and foremost, it could be said that the Arms Trade Treaty is a more a normative aspect to the global governance of the arms trade. History shows us many efforts to regulate weapons. Within the need to address the constant globalising challenges that we face, the paradigmatic shift towards globalisation must be intuitive to the history of the arms trade in order to accommodate this shift. In other words, in order to appreciate the normative significance of the ATT and other global laws and norms, one must look to the past.

The League of Nations indicated one shift in history towards a collective security system and an acknowledgement that previous limitations and prohibitions on the trade of 
arms did not suit present requirements. The Brussels Act, The Hague Conventions of 1899 and 1907 and the Convention for the Control of the Trade in Arms and Ammunitions, signed at St. Germain-en-Laye in $1919^{11}$ all involved measures to regulate trade in arms. The League did, however, integrate the St. Germain Convention due to their aligning purpose. The Convention sought to prohibit arms transfers to non-Western countries to protect European empires, later interpreted to also mean non-state actors and semi-civilised nations. ${ }^{12}$

Although the League is often known for its failings, its attempts to regulate the arms trade shows a somewhat different story. This was not one of complete success, as national self-interest overrode these efforts. Whilst the will of the superpowers-based in the fear of instability on their colonial empires ${ }^{13}$ - and need for operational and good international management was strong, smaller powers' refusal to allow what they perceived as the infringement of sovereign rights posed as an obstacle to these aims, eventually superseding them.

Nonetheless, the League of Nation's moral influence and impact is evidence of the normative legacy it left behind in its mandate to control the global arms trade. It is this normativity, even without global consensus, that has significant value and opens up the doors for future processes of law-making, as well as similarly playing out in today's world of global aims to control the arms trade. In many ways, then, the discourse on how to effectively harmonise legal processes and products with globalising societal factors is very much a question of history, as well as one of the here, now and beyond.

Other experiences with the Convention on Certain Conventional Weapons, the UN Register of Conventional Arms 1991 for transparency and the Wassenaar Arrangement 1996 - a voluntary export control regime - were regulation attempts, but were not comprehensive. Precursors to the ATT were the ECOWAS Convention on Small Arms and Light Weapons and the EU Common Position on Arms Transfers. Whilst there are, to a degree, some overlaps between, for example, the ECOWAS Convention and the ATT, the ATT emits new global norms on arms to regulate international transfers of all conventional arms. With all these changes and developments of the arms trade occurring over time, there are several observations that need to be made in order to align security priorities with the globalising landscape. This section will attempt to extract various elements to a suitable kind of global law for the global arms trade.

One of the key difficulties in propounding law-or at least making sense of possible global legal progression-in times of increasing globalisation is its mushrooming multifacetedness and interdisciplinarity. Looking at it from a transnationalist's perspective, a methodology is required aimed 'at capturing globalisation's effects on norm creation, and the types and sources of legal outputs that result.. ${ }^{14}$ We need only look at the role of multinational corporations dealing in arms to see this interdisciplinary illustration first hand and,

${ }^{11}$ The General Act on the Slave Trade and Importation into Africa of Firearms, Ammunition, and Spiritous Liquors, signed in Brussels, 2 July 1890; Convention (II) with Respect to the Laws and Customs of War on Land and its Annex: Regulations concerning the Laws and Customs of War on Land, The Hague, 29 July 1899; Convention (IV) respecting the Laws and Customs of War on Land and its Annex: Regulations concerning the Laws and Customs of War on Land. The Hague, 18 October 1907; The Convention for the Control of the Trade in Arms and Ammunitions, signed at St. Germain-en-Laye, 10 September 1919, 225 CTS 482.

12 David R. Stone, Imperialism and Sovereignty: The League of Nations, Drive to Control the Global Arms Trade 35(2) J. Contemp. Hist. 213, 218 (2000).

${ }^{13} I d$., at 214.

${ }^{14}$ Frank J. Garcia, Law and Globalization: Conceptual Issues, TLI Think! PAPer 33, 6 (2016). 
in many ways, see the existence of a whole host of pluralistic environments moulding law's form and substance. ${ }^{15}$ In addition, one cannot escape the inference here that aspirations for global law may be inherently delusional and in no real sense able to fundamentally impart standardised norms that bring all actors and processes together in harmony. Perhaps, in order for us to realistically evolve in our understanding of global law, we must see it as synonymous to legal processes within both the domestic and international realms, including the marriage of both, as they react and tackle globalising problems.

Additionally, or alternatively, one may look to the work of Ziccardi Capaldo, which negates this contention and which talks of the 'pillars of global law.' It is hard to deny that global law has a transmutative nature, which in particular, involves the transmutations of international law into a mosaic of converging and diverging norms. Ultimately, regardless of the multitude of norms, values and rules that are evident, a process of cross-fertilisation brings to the forefront Ziccardi Capaldo's distinct pillars - verticality; legality; integration and collective guarantees. They demonstrate the systemic evolutionary attributes conveyed through globalisation, such as procedural changes for the execution of global law; the restructuring of legislative tools; and demands for mutually recognised burdens and duties to protect the global legal order from threats (old and new) to global peace and security; to facilitate economic development and a sustainable approach to the environment. These pillars also play their role as strived-for ideals ${ }^{17}$ and form a constitution for the global legal system.

When attempting to govern the arms trade, as affecting overlapping legal systems, one quickly becomes aware of the closeness and interaction of those within the world. In this sense, to avoid fragmentation and the unjust forum shopping that was mentioned in the introduction of this article, there needs to be a way of organising this incipient globe of structures that have mutually aligning attributes. Global law should deal with various governing bodies subsisting together-not necessarily harmoniously-in a way not enforced by the ruling of their states. These societies are not identical, with different population size, institutional character and geography, to name a few differences. Global societies are therefore diversely operational, systemised in a way relevant and desirable to them for the purpose of shared advantageous aims and expectations.

In attempting to create law for a global field such as the arms trade, global law must have a function that equalises the gradation of authority that not only accounts for the role of states, but non-state actors, as well as other communities. The law must reflect their will and indicate the globalising effect of the fragmentation of power structures. Globalisation has shown the power emitting from non-state actors and non-governmental organisations ${ }^{18}$ that both possess an independence similar to that of self-government. Multinational corporations, in particular, are one such example of an actor able to apply this type of authority within their supply chain processes. ${ }^{19}$ Functions could include self-certification and

15 Peers Zumbansen refers to this as transnational legal pluralism. See Peers Zumbansen, Transnational Legal Pluralism, 1 Transnat'L Legal Theory 141 (2010).

16 Giuliana Ziccardi Capaldo, The Pillars of Global Law (2008).

17 Id., at 16.

${ }_{18}$ Thomas G. Weiss, D. Conor Seyle \& Kelsey Coolidge, The Rise of Non-State Actors in Global Governance: Opportunities and Limitations, One EARTh Future Discussion PAPER (2013). Margaret A. Young emphasises the role of non-state actors in regime interaction, but refutes any claim that they possess sovereignty. Margaret A. Young, Fragmentation, Regime Interaction and Sovereignty, in SovereIGNTY, Statehood and State Responsibility 78 (Christine Chinkin \& Freya Baetens eds., 2015).

${ }^{19}$ Larry Cata Backer, Multinational Corporations as Objects and Sources of Transnational Regulation, 14 ILSA J. INT'L \& Comp. L. 499 (2008). 
standard-setting, but in general include functions directing the evolution of shared practices, procedures and, ultimately, norms.

Demonstrating this to a $\mathrm{T}$ are corporations that trade in arms, which flaunt the extraction of private forms of governance from beneath the cover of states and, arguably, the law. Global law is therefore no longer solitary, but interactive between, amongst, within and without the emerging (and emerged) global entities. It also requires the connections between the law, legitimacy and democracy to play out within governing societies embedded within different cultures, histories and socio-economic needs. This is not to advocate for a global legal system that is devoid of any state power. On the contrary, the state is very much alive and kicking, but must re-order and re-manage power in a way that is inclusive of privatisation and the management of non-state and non-governmental organisations.

Global law must exhibit the will of the group, such as non-state actors within the arms trade community, and delineate rules that arise as a result of the constitutional rules of that community. Following from that, these global rules must allow the community to apply and adhere to those rules, whilst allowing for the materialisation of penalties for possible infractions. Ultimately, this asserts the need for rules transcending the national, and the collective national, to circumvent the public and private divide ${ }^{20}$ and propound a self-constituted logic. It takes into account the complexities and assembly of an innumerable and mixed breed of governing entities. There must be operational freedom (to a degree) and instruments allowing dispute settlement embedded within its framework. This also applies to the normativity that seeps from the prospects and probabilities of community members, which if we look at the arms industry would include, for example, governmental bodies, investors, consumers, exporters and importers.

One of the points that was brought to light during the negotiation process of the ATT was the inability to achieve consensus on key provisions. This struck at the core of what the UN system was all about, which strives to preserve states and stabilise the international system that is self-obligatory and consensual amongst states, as cemented within a plethora of conventions as well as in customary law. With globalising arms trade processes having impact in a far-reaching way, with a limitless evolutionary prospective, global law must embrace the mutations and shapeless form that come with such an industry and its actors. Here, the markets may be seen to be applicable, where 'consumer choice, civic activism and public engagement are also indicative of this altering environment, albeit in a manner that may well lack cohesion due to both the differing behaviour of new governance processes and the resistance fostered by traditional ones. ${ }^{21}$

Paradoxically, the globalised nature of the arms industry calls for a global type of law that manages and organises mutations as a consequence of the flow of objects, information, products and people through haphazard processes. Globalisation infers a reincarnation of customs that move with the 'flow' aforementioned to re-emerge as different entities and this plays out in a never-ending story. So the law must cater for these transformations and, equally, transportations. Similarly, in creating laws to adequately contend with and

\footnotetext{
${ }^{20}$ Christine Chinkin, A Critique of the Public/Private Dimension, 10 Eur. J. InT'L L. 387 (1999); Gillian K. Hadfield, The Public and the Private in the Provision of Law for Global Transactions in Contractual Certainty, in International Trade: Empirical Studies and Theoretical Debates on Institutional Support for Global Economic Exchanges (Volkmar Gessner ed., 2009); Lorenzo Casini, Down the Rabbit-hole: The Projection of the Public/Private Distinction Beyond the State, 12 InT'L J. Const. L. 402-428 (2014).

${ }^{21}$ Jeffrey Roy, E-Government, Good Government and Knowledge Management, 6 J. Electronic Com. Res. 44, 47 (2005).
} 
accommodate the arms industry — at one and the same time — and the potential for new technologies that are advancing constantly, there must be a legal agility to cater for capricious hurdles. This poses the problem of balancing the strife for legal agility with certainty as an inherent character of the law. A question must be asked then whether a new approach to globalisation requires the forfeiture, or less severely, reconsideration of customary rules and what advantages and disadvantages may be brought with it. The rapid technological advancement of weapons, in a faster-turning globalising wheel, often demonstrates the lingering nature of the law, which requires more reactive methods and approaches to safeguard against and prevent any potential atrocities or victimisation which may occur.

There are obvious dangers to the legal speed and agility that globalisation requires. If, for example, the legal responsiveness to technological developments in the arms industry means calls for a review of already-existing law in order to relax provisions, there is a risk that the entirety of law will disentangle to lose safeguards that have been fought for in its negotiation process. Retackling an embedded normative framework then can also work against any intended goals that may in reality, as part of the globalising momentum, be short-lived. The anticipated positives must outweigh the negatives. It is this balancing act that is difficult to achieve and it must be asked whether jeopardising the respect for existing law - and potentially inflame previous contentions - offsets what could be a limited gain. ${ }^{22}$

A global legal process that effectively regulates the arms industry must also be mindful of the intertwinement and absorption of geographic boundaries, given that the supply chain is not isolated within one single system or affects one single entity. Global movements mean that products, values, data from one entity can quite easily affect another. This also applies to processes within one industry that can quite easily affect other industries or aspects of society. The arms industry, again, is a good example of how business can quite directly affect the often seen to be different field of human rights. More specifically, the UK sale of arms to Saudi Arabia and subsequent human rights violations in Yemen proves this point. An arms corporation with a worldwide setup may forum shop or be seen to alter the way in which traditional local legal regimes apply their local laws. Larry Cata Backer states that the 'convergence of form suggests a functional convergence of governance-the private corporation with public obligations, and the regulatory state that participates in markets. Public and private corporate bodies, once divided by an insurmountable conceptual barrier, now become mirrors of one another. ${ }^{23}$ On this, he refers to a type of porousness in which 'multiple governance regimes' applying to a single body will permeate that body, leading to a response involving the subsequent internalisation of that regime. ${ }^{24}$

The supply chain within the arms industry shows the way different actors within this chain are governed by multiple systems of rule due to transnational processes, continuously crossing borders vertically, horizontally, diagonally and in other erratic ways. These diverse relationships are being played out constantly and call for a system that appropriately and effectively organises the arms industry and its interrelation with other fields such as human rights. The next section will delve into the Arms Trade Treaty and discuss whether this global treaty embodies these elements.

\footnotetext{
22 William H. Boothby, Weapons and the Law of Armed Conflict 365-366 (2016).

${ }^{23}$ Larry Cata Backer, Private Actors and Public Governance Beyond the State: The Multinational Corporation, the Financial Stability Board, and the Global Governance Order, 18 Ind. J. Global Legal Stud. 751, 759 (2011).

${ }^{24}$ Reflections on Global Law (Shavana Musa \& Eefje de Volder eds., 2012); Larry Cata Backer, The Structural Characteristics of Global Law for the 21st Century: Fracture, Fluidity, Permeability, and Polycentricity, 17 Tilburg L. Rev. 177 (2012), 193.
} 


\section{THE ARMS TRADE TREATY}

The General Assembly of the United Nations adopted the Arms Trade Treaty (ATT) on 2 April 2013. This had been a long journey of undulations, particularly since the treaty text had been rejected twice already by the conferences, prompting the General Assembly to resort to adoption by vote. The previous failures to adopt were related to the stringent rule of consensus prescribed by the rules of procedure. Under Article 21(1) of the AT, the treaty could be signed at the United Nations in New York from 3 June 2013 until 24 December 2014, when it came into force. During the final diplomatic conference, however, disagreements about the treaty text were brought on by Iran, Syria and the Democratic People's Republic of Korea, which placed a halt on any chance of smooth negotiations. It had not been the first time that the consensus rule had caused disruption. The rule had previously been an obstacle during the Conference on Disarmament in 2013, which did not result in much.

The Arms Trade Treaty's imperfections were also criticised by India, China and Russia. These countries, as part of the group of main exporters of arms, refrained from the key UN General Assembly Resolution passage that gave way for the treaty. Arguments against came in the form of self-defence or the fact that the ATT would allow exporting entities to dictate what constituted violations of international human rights and humanitarian law. Countries such as North Korea also argued that the evident imbalance in the international system meant that superpowers would never be held liable for such violations as they believed that the assignment of guilt was essentially linked to the substantive inability and fragility of an actor. So the ATT was innately designed in favour of exporters over importers. Russia also spoke of the insufficient provisions for the prohibition of arms transfers to non-state actors. These ups and downs in the negotiation process demonstrated a larger picture of (difficult) global law-making, one that is worthy of note and one that highlighted that the parties involved in the negotiation process had ' $[\mathrm{n}]$ o consensus on what consensus' meant. ${ }^{25}$

Whilst this was one instance in which the global community came together to bring about a global treaty, the lack of consensus and turn to adoption through voting undermined state integrity and desire. ${ }^{26}$ The United Kingdom, Australia, Japan and Costa Rica presented a draft resolution in order to adopt the treaty by vote. The UN General Assembly approved this motion and adopted the resolution.

Regardless of the lack of consensus and endless disagreements amongst states, the ATT was deemed a historic document, not simply because of its global multilateral nature, but also because of its mandate to regulate the transfer of even conventional arms. Its existence alone may even be enough to have normative impact and trigger further norms. The treaty placed human rights and humanitarian law at the core of decision-making on the arms trade. If applied strictly and effectively, it could limit the illegal use of arms and hinder the exacerbation of conflict around the world by states and non-state actors such as terrorists and warlords. In turn, this would minimise civilian injury and deaths. ${ }^{27}$ The adoption of the ATT recognised the human cost of insufficient and poor regulation of conventional arms.

Due to the globalised character of supply chains in the arms industry and the need to instil regulation for global processes without placing unrealistic burdens on stakeholders,

\footnotetext{
${ }^{25}$ Reaching Critical Will (2012) Arms Trade Treaty Monitor, available online at <http://www. reachingcriticalwill.org/images/documents/Disarmament-fora/att/monitor/>, 3-4.

${ }^{26}$ S. Lorthois Louembet, Vers un traite international reglementant les transferts d'armes classiques en 2012, CXIV 4 Revue Generale de Droit International Public 723-724 (2010).

${ }^{27}$ Ban Ki Moon, Statement: Secretary-General's Statement on the adoption of the Arms Trade Treaty (April 2, 2013), available online at <http://www.un.org/sg/statements/index.asp?nid=6708>.
} 
the industry itself also had input in many aspects of the Arms Trade Treaty. There was therefore some optimism by the industry itself in achieving more sustainable practices and, in many ways, consolidating regulatory frameworks that are often fragmented due to the involvement of various actors from various national regimes.

The ATT was seen to be different from previous attempts to tackle the illicit arms trade by extending its focus to beyond simply the trading issue of arms. For the first time, it placed an obligation on states to analyse the consequences and effects of arm exports. It acknowledged the strong causal links between the export of arms and the acts of violence taking place on innocent civilian populations, particularly on women and children. It integrated concepts of transparency and accountability into the regulatory processes at hand. For example, the First Conference of States Parties in 2015 made the decision to allow civil society to attend meetings relating to the ATT. The ATT also required states to retain all records of authorised and actual transfers of conventional arms. Details of these transfers were to be submitted via a report to the treaty's Secretariat. Additional state party reporting was to consist of information on national laws, policies and administrative measures adopted by states. By embedding a degree of transparency into decision-making processes, there was an intention to decrease any leeway the states may have had in entering into trading deals with actors that could be responsible for violations of international humanitarian law and human rights abuses. The fact that these reports would not automatically be available to the public, however, seriously hampered this intention. States had to give their consent for this to occur.

The object and purpose of the treaty is laid out in Article 1 of the ATT and is 'guided' by the UN Charter. The Charter 'seeks to promote the establishment and maintenance of international peace and security with the least diversion for armaments of the world's human and economic resources (...). ${ }^{28}$ There is a direct link between the regulation of the arms trade and the maintenance of peace and security, which the United Nations confirms in a number of ways. ${ }^{29} \mathrm{~A}$ study by the International Committee of the Red Cross also showed that the widespread availability of arms increased violations of international humanitarian law, causing severe injury to the civilian population. ${ }^{30}$

Article 1 of the ATT describes its purpose as to contribute towards international and regional peace, security and stability; reduce human suffering; and promote cooperation, transparency and responsible action by states in the international trade in conventional arms, building confidence amongst them. The purpose would be achieved by establishing the highest possible common international standards for regulating or improving regulation of the international conventional arms trade. The treaty also seeks to prevent and eradicate the illicit trade in conventional arms. The fact that the ATT refers only to 'illicit' trade in its objective means that the interpretation of the wording does not include restrictions on lawful arms transfers, contrary to the opinions of many states that did in fact want to regulate transfers to states where arms would be used lawfully. As mentioned above, Iran, Syria and the Democratic People's Republic of Korea did not support the ATT at the conference in 2013, as it did not ban transfers to rebel groups.

\footnotetext{
${ }^{28}$ Article 26 of the Charter of the United Nations.

${ }^{29}$ UN Security Council, 7036th meeting report, S/PV.7036 (2013). Also see a comprehensive annotation of the Arms Trade Treaty by the Geneva Academy, Academy Briefing No. 3, The Arms Trade Treaty (2013).

${ }^{30}$ ICRC, Protecting Civilians and Humanitarian Action through the Arms Trade Treaty, available online at <https://www.icrc.org/eng/assets/files/publications/icrc-002-4069.pdf>. Also see International Committee of the Red Cross, Arms Availability and the Situation of Civilians in Armed Conflict, ICRC Publication, ref. 0734 (1999).
} 
The treaty, however, is explicit in its aims to protect national sovereignty and selfdefence. It contains a paragraph in its preamble which reaffirms 'the sovereign right of any State to regulate and control conventional arms exclusively within its territory, pursuant to its own legal or constitutional system. The inclusion of this in the text means that the regulation of domestic trade of conventional arms solely within the national borders of a country is outside the scope of the ATT. The ATT only affects international transactions and not ones within the territory of a state. Additional safeguards on national sovereignty were included in Article 24 of the treaty, where states are given the right to withdraw from the treaty and 'may' include reasons for withdrawal, the latter not being mandatory.

The ATT further allows for states to adopt 'additional effective measures to further the object and purpose' of the treaty. This means that states are free to enhance their national security laws and policies even for circumstances permitted by the ATT. This affirms the sovereignty of a country and permits states to strengthen their capacity to facilitate peace and security. Since the ATT functions in accordance with the principles of the UN Charter, states retain their 'inherent right' to 'individual or collective self-defence' as per its Article 51 . However, should states take the opportunity to nationally enhance the regulation of the arms trade, within their own capacity and as emphasised by the ATT, then the need to use self-defence measures after the fact would be minimised.

A further principle that the ATT adheres to is the principle of non-intervention in matters which are essentially within the domestic jurisdiction of any State. This principle is based on Article 2(7) of the UN Charter and affirmed in the UN General Assembly's 1970 Declaration on Principles of International Law Concerning Friendly Relations and Cooperation among States, as well as in Article 41 of the Vienna Convention on Diplomatic Relations. This, again, ensures the national sovereignty of a country, where states are not directly or indirectly able to intervene in both the internal and external matters of another state. $^{31}$

The treaty respects the need for states to acquire conventional arms to exercise selfdefence and for peacekeeping missions. It also respects the interests of states to transfer conventional arms. Whilst the respect for this is not framed as a right as such, the treaty does deem it a legitimate interest and it could be viewed more broadly in light of other General Assembly Resolutions that do refer to a state's 'right' to produce and transfer arms. ${ }^{32}$

\section{A. Failings and Possible Amendments}

The provisions of the ATT that are described above highlight its positive content, but in many ways, the ATT can be seen as being too good to be true. The speedy process of eighteen months in which the treaty went from non-existent to functional and ratified within a number of countries may ring alarm bells to some. And in many ways, they would be right, since the treaty has evident weaknesses. Commendably, the treaty itself does have a humanitarian character, more than any other treaty dealing with the arms trade. However, the focus on arms transfers means it cannot be strictly categorised as a law of armed conflict document.

\footnotetext{
${ }^{31}$ In addition to the Agreements stated in the text, the issue of intervention has developed through case law such as United Kingdom v. Albania (The Corfu Channel Case) [1949] ICJ Rep. 4; Military and Paramilitary Activities in and against Nicaragua (Nicaragua v. United States of America), Judgment (June 27, 1986).

32 United Nations General Assembly, Resolution Adopted by the General Assembly on 2 December 2009, A/RES/64/48 (2009).
} 
More important, despite the fact that at the moment the ATT is in force, there are still many significant arms exporters and importers from around the world that have not yet ratified the ATT. Whilst the current participation of states is promising, there are countries, such as China and Russia, that have not yet embraced the ATT. In order for the ATT to be fully effective, it is imperative that it has global involvement for global impact. Failing to achieve widespread effect would increase the risk of international crimes taking place, such as genocide and crimes against humanity. The true value of the treaty can also only be measured based on its ratification by states. It is problematic if many states have not ratified and in this case, it is of concern that countries such as the United States, China and Russia, as big military players and significantly large exporters of arms, have not. Russia and China have not even signed the treaty. This lack of ratification and in some cases, signature, hugely impairs the global nature of the ATT and, inevitably, questions its practical impact beyond a scrap of paper.

There were also exclusions within the treaty that have sparked further criticism. For a start, the ATT's focus on transfers meant that the regulation for the wider industry was not what the treaty was about and failed to take into account how to regulate the arms trade as a whole. In addition, it did not deal with the physical transfer of weapons outside of the domestic sphere, but via legal ownership. Some claimed that this inferred that transfers must be of a commercial orientation, which would hinder the scope of the treaty. This is significant given the gifting of weapons by states to their allies, as was done by the United States in the Cold War-now brought under counter-terrorism strategies, as well as UK practices of gifting to Iraqi and Kurdish governments in the fight against the Islamic State. ${ }^{33}$ However, clarification from the United States included gifts within the meaning of 'transfer.'34

Unfortunately, whilst the ATT can be seen as a landmark treaty, recent events have already brought to light the adjustments that countries still need to make in order to adhere to these global obligations on arms exports. The United Kingdom constitutes one such example country that despite championing the treaty from the outset violated the ATT through sales to Saudi Arabia, demonstrating the complexities surrounding implementation of global norms within domestic frameworks. The United Kingdom's practices on its defence exports could be viewed as contravening its international obligations under the treaty, rendering them in violation of international laws. The reasons for this are listed in the proceeding paragraphs.

Article 6 of the ATT sets out three prohibitions imposed upon a state. Article 6(1) prohibits transfers that violate a state party's obligations under measures adopted by the UN Security Council. Article 6(2) prescribes that state parties shall not authorise transfers that would violate 'relevant international obligations' under international agreements that it is a party to. This clause quite clearly excludes agreements that states have not signed, but possibly less apparent, also excludes customary international law from its premise. These exclusions widen the limitations of the ATT, as they allow state parties to decide what in their view is 'relevant', as well as allowing them to avoid the consideration of international agreements that contain critical provisions due to them not being party to them.

Focus should also be paid to Article 6(3) where a 'State Party shall not authorize any transfer of conventional arms (...) or of items covered [by the treaty], if it has knowledge at

\footnotetext{
${ }^{33}$ Nina M. Serafino, Congressional Research Service, Security Assistance Reform: "Section 1206" Background and Issues for Congress, 7-5700, RS22855 (2014).

${ }^{34}$ US Department of State, Arms Trade Treaty, FACt SHeEt (June 4, 2010), available online at <http://www. state.gov/t/isn/armstradetreaty/>.
} 
the time of authorization that the arms or items would be used in the commission of genocide, crimes against humanity, grave breaches of the Geneva Conventions of 1949, attacks directed against civilian objects or civilians protected as such, or other war crimes as defined by international agreements to which it is a party. ${ }^{35}$ The text of this article is progressive in many respects, providing that the definitions for such things like genocide, crimes against humanity, civilians in the mentioned legal instrument, as well as others that have followed since, such as its Additional Protocols, the Rome Statute, supplementary International Committee of the Red Cross (ICRC) commentary, etc., are heeded. However, given that many countries are not party to these international legal instruments, there is once again the problem of how effective the ATT will be in the implementation phase.

The United Kingdom, surprisingly, has already shown to be in violation of Article 6(3) of the treaty through the transfer of weapons to Saudi Arabia. Saudi Arabia was already established as a country of concern by the UK Government, as stated in the Foreign and Commonwealth Office's Human Right and Democracy Report. ${ }^{36}$ The Saudi-led coalition's intervention in Yemen constitutes grave breaches of the Geneva Conventions 1949, particularly under Geneva Convention I, Article 19, ${ }^{37}$ where medical units and establishments may in no circumstances be attacked, as well as Article 50 outlining 'grave breaches. ${ }^{38}$ The Saudi-led intervention has also involved attacks directed against civilians, ${ }^{39}$ which violate the principle of distinction and the principle of proportionality ${ }^{40}$ under customary international humanitarian law. ${ }^{41}$ Other war crimes, as per international agreements such as the Rome Statute of the International Criminal Court that the United Kingdom is party to, could also be established as a result of this. ${ }^{42}$

${ }^{35}$ Article 6(3) of the Arms Trade Treaty.

${ }^{36}$ Foreign and Commonwealth Office, Human Rights and Democracy Report 2013, Section XI, available online at <https://www.gov.uk/government/publications/human-rights-and-democracy-report-2013/ human-rights-and-democracy-report-2013>.

37 Article 19, Geneva Convention I.

${ }^{38}$ Article 50 Geneva Convention I.

39 See UN News Centre, In Wake of Another Deadly Attack in Yemen, UN Human Rights Chief Decries Coalition Airstrikes, available online at <http://www.un.org/apps/news/story.asp?NewsID=53480\#.V0wqbSMrLjB >; United Nations Human Rights Office of the High Commissioner, Zeid Condemns Repeated Killing of Civilians in Yemen Airstrikes, available online at <http://www.ohchr.org/EN/NewsEvents/Pages/DisplayNews. aspx?NewsID=17251\&LangID=E >; NEO Outlook, The Bitter Lessons of the Military Intervention in Yemen, available online at <http://journal-neo.org/2016/04/08/the-bitter-lessons-of-the-military-intervention-inyemen/Amnesty>. International UK, Yemen: UN Inquiry needed after six months of devastating Saudi-led intervention, 25 September 2015; ABC News, Yemen Conflict: Death Toll from Saudi-Led Air Strikes on Market Rises to More than 100, UN Says, available online at <http://www.abc.net.au/news/2016-03-18/death-tollfrom-saudi-air-strike-in-yemen-rises-to-more-than-100/7256700>,17March2016; TheGuardian,UNReport into Saudi-led Strikes in Yemen Raises Questions over UK Role, available online at <http://www.theguardian. com/world/2016/jan/27/un-report-into-saudi-led-strikes-in-yemen-raises-questions-over-uk-role>.

${ }^{40}$ Article 51(5)(b) Additional Protocol I, Geneva Conventions.

${ }^{41}$ See Articles 51, 52, 57 of Additional Protocol I. Further explanations can be found at ICRC, Rule 1: The Principle of Distinction between Civilians and Combatants, Chapter 1. See Practice relating to Rule 14, Principle of Proportionality.

${ }^{42}$ The author has assessed the Yemen situation in-depth and concurs with the findings on the ATT included in the 2015 Legal Opinion by Professor Philippe Sands, Professor Andrew Clapham and Blinne Ni, The Lawfulness of the Authorisation by the United Kingdom of Weapons and Related Items for Export to Saudi Arabia in the Context of Saudi Arabia's Military Intervention in Yemen, available online at <http://www.saferworld.org.uk/resources/ 
Whilst the UK Government may take into account assurances made by Saudi Arabia on prohibited action under Article 6(3) of the ATT, it is essential that these are not the sole basis for transfers, particularly since Saudi Arabia is a country of concern. The apprehension and care needed when assessing an arms transfer has also been confirmed by cases such as $R$ v. Secretary of State for Trade and Industry.$^{43}$ Here, the secretary of state affirmed that 'due to the misuse of a particular export, the Secretary of State would not rely on assurances about the extent of the intended use given by the Israeli authorities'. If the United Kingdom had knowledge that Saudi Arabia would commit prohibited practices as stated in Article 6(3), then the United Kingdom would be in contravention of the ATT. The end use of arms following a transfer is very much the concern of the United Kingdom under its international obligations under the ATT.

The ATT is far from perfect textually and there are ways in which possible amendments could be made to enhance its effectiveness. Article 7 under the treaty is one of the most important yet simultaneously most contentious treaty articles. Under this article, the criteria for export assessment were decided as two-pronged. Exporters had to assess whether any prohibitions under Article 6 existed in the process of export licensing. Following on from this, if an exporting state decided that no prohibitions applied, the state would move onto the second criterion that allowed the exporting state party to take into account 'relevant factors' and 'assess the potential' in 'an objective and non-discriminatory manner' of an importing state to be an international humanitarian law violator or to assess whether the transfer would contribute to peace and security, etc. The full criteria list is not detailed here, but suffice to say it is the exporter that has the leeway to judge this and makes room for judgment to be made with self-interest at its heart.

Article 7 is therefore a 'get-out' clause, as a transfer may be unlawful under the ATT, but an authorisation of that transfer by a state may be legal through establishing that a transfer's impact on peace and security would be contributory and not undermining. Alternatively, other non-just reasons could result in a transfer authorisation. In order to provide clarity and prevent states from benefiting from this apparent loophole, additional detailed guidance on how states should undertake their risk assessments and tests in determining the effects of the transfer would have been, and still is, welcome. It would have been more beneficial to integrate within the risk assessments, specificities that require exporting states to look at the number of exported weapons and their normal usage to an importing country, an obligation to undertake an in-depth study on the beneficiary state, as well as in the importing state's region. Furthermore, the inclusion of an interpretive organ, administrative body or provision defining assessment would have mitigated the ability of exporters to apply a biased approach. Any enforcement body would have severely hampered the materialisation of the treaty as an infringer of national sovereignty and therefore the balancing act swayed in favour of its absence. ${ }^{44}$

Article 7(2) of the ATT on the Export and Export Assessment refers to 'measures that could be undertaken to mitigate risks'. These could include 'confidence-building measures or jointly developed and agreed programmes by the exporting and importing States'. In order to enhance effectiveness, more guidance should be provided on how states could mitigate risks with the importing state. The current ambiguity surrounding possibilities for

view-resource/1023-the-lawfulness-of-the-authorisation-by-the-united-kingdom-of-weapons-and-relateditems-for-export-to-saudi-arabia-in-the-context-of-saudi-arabias-military-intervention-in-yemen>, at 38 et seq.

${ }^{43} \mathrm{R}$ (on the application of Hasan) v. Secretary of State for Trade and Industry [2007] EQHC 2630 (admin).

${ }^{44}$ See Laurence Lustgarten, The Arms Trade Treaty: Achievements, Failings, Future, 64 InT'L \& Comp. L.Q. 569, 591-592 (2015). 
mitigating measures does not provide states the incentive to implement such measures. However, with detailed specifications and increased practice, measures could be integrated into the Export Assessment more comprehensively. For example, the integration of international humanitarian and human rights law as a priority must be indicated from the outset to the importing state, which could include training programmes on such issues. Contractual agreements and licences must also be supplementary to the dialogue and training, in order to insert clauses that make it clear that the exporting state will not transfer arms to countries where they could be diverted. There must be enhanced information exchange between exporting and importing states. The ATT should include detailed guidance on the measures that states must take should they discover reasons to not authorise an arms transfer after an authorisation has in fact taken place. A stricter obligation on reassessment should therefore be integrated into the treaty. Risk assessments should also include reference to gender-based violence, given the causal link between the arms trade and violence specifically related to gender. ${ }^{45}$ The same applies to violence against children.

In fulfilling its obligations, the United Kingdom should also have performed a full risk assessment, in an 'objective and non-discriminatory manner' under Article 7 of the ATT, where an export was not completely prohibited. ${ }^{46}$ The United Kingdom had to ensure that the export would not undermine peace and security. Even if the assessment showed that it would not, the United Kingdom would still have to assess whether the export could be used to 'commit and facilitate' a serious violation of international humanitarian law, international human rights law or an act constituting an offence under international conventions or protocols relating to terrorism or transnational organised crime that the United Kingdom was party to. As far as Saudi Arabia is concerned, it should be questioned whether any assessments complied with the requirements outlined in the treaty, or were even taken heed of, as various reports and on-the-ground commentators have confirmed the serious humanitarian and human rights abuses taking place in Yemen. ${ }^{47}$

The adoption of reporting templates for states-on the implementation of the treaty, but also for the authorisation of arms transfers-would enhance the effectiveness of the treaty and guide states on the level of transparency required under this duty to report. Whilst a working group is being planned to deal with this issue, a priority should be placed on this, as it is crucial for the achievement of the ATT's underlying goals. The public disclosure of reports should also be made mandatory.

The ATT is also absent of provisions on future weapons technology, such as autonomous weapons systems, nano-technology and drones. This was troubling for some states during the negotiations, particularly since complex technological equipment was widely used during the Arab Spring by some authoritarian regimes. In addition, it was made clear that stringent rules and regulations on national licensing that may have existed for traditional weaponry did not exist for new technological weapons, mainly owing to the definitional ambiguity of what constituted arms. ${ }^{48}$ Although the Wassenaar Agreement covered,

\footnotetext{
${ }^{45}$ Ray Acheson \& Mia Gandenberger, Gender-Based Violence and the Arms Trade Treaty, in ReAching Critical Will of the Women's International League for Peace and Freedom (2015).

46 See Article 7 and 8 of the Arms Trade Treaty.

47 See Sands et al., supra note 42; Security Council Report, Yemen (2016), available online at <http://www. securitycouncilreport.org/yemen/>.

48 Roger Brownsword \& Karen Yeung, Regulating Technologies: Legal Futures, Regulatory Frames and Technological Fixes (2008); Jakob Kellenberger, International Humanitarian Law and New Weapon Technologies (Sept. 8, 2011), available online at <https://www.icrc.org/eng/resources/ documents/statement/new-weapon-technologies-statement-2011-09-08.htm>.
} 
in part, some new technology, ${ }^{49}$ more extensive global regulation was required, but the ATT failed to deliver on this front and did not include certain rife new technology within its designated classifications of conventional arms. It has been agreed that there will be room to make amendments, but since this is not possible until six years post-force, its complete absence at the outset places the treaty on shaky ground and given the serious possibility for the escalation and evolution of new technological weaponry, such as weapon-detection systems, to dominate the global sphere and in fact cancel out some of the value of the ATT in the meantime.

The lack of provision in the ATT for new technologies means that along with insufficient customary principles, it remains to be seen whether the development of technological weapons of humanitarian concern can in fact be minimised or outlawed completely. As Boothby suggests, whilst 'principles of humanity and the dictates of the public conscience' may inspire ad hoc treaty provisions for these kinds of advancements in technology, they will not affirm any criteria for the legality of weapons, ${ }^{50}$ especially since history indicates the predisposition for law to follow technological developments, rather than vice versa.

\section{CONCLUSION}

The arms industry is notoriously complex and metamorphic. As well as the deeply sensitive nature surrounding the military and defence purpose of arms and the susceptibility of arms to fall into the wrong hands, there come many challenges to effectively regulating this type of trade. As the example of the United Kingdom has shown, if not done properly, there can be dangerous consequences. The question then comes-as one this article has not necessarily answered, but attempted to deliberate over-is how to regulate an everglobalising industry if one perceives the current state of the art as lacking. The recent Arms Trade Treaty cannot escape this discussion.

One important point that has come from the assessment of whether and how global law (and norms) should be imparted in light of increasing globalisation, and more specifically, the ATT, is that despite the hybrid movements and processes that society is experiencing, as well as the heterogeneity of actors, the state is far from redundant. In fact, states are crucial to legal negotiation processes, to the clarification and understanding of global law (and norms), to the creation of customary law and to the adherence to those laws. The ATT is a prime example of global idealism in action that, at the very least, in applying rules to the arms transfer process could significantly reduce illegal diversion of arms and, consequently, reduce the risk of human rights and humanitarian law violations. However, it is, in some ways, also a hollow attempt at regulation and applying a human-centred approach to the arms trade without states wholeheartedly subjecting themselves to the provisions through ratification. Ideally, states, that have not already, must be urged to provide their signature, ratification and implementation of the ATT as soon as possible, in order to achieve global adherence to the treaty, as required for effective and full impact. With countries like Russia and China not signing or ratifying the treaty, it begs the question how globally effective it can be. This latter point has time and again, with many international legal instruments alike, proven to be the greatest obstacle in materialising a global kind of law into global legal practice.

The negotiation process leading up to the treaty also illustrated the consensus principle as a double-edged sword. With a united front and agreement from states, the ATT had the

\footnotetext{
${ }^{49}$ It was not included in the initial Wassenaar list, but later added some decades after it was originally created.

${ }^{50}$ Bоотнву, supra note 22, at 362 .
} 
potential for substantive and powerful force to regulate the transfer of arms, but without, left a diluted document that as of now has been thrust towards the ideal and left the real and practical elements trailing behind. In the same way, it shines a torch on the difficulties of multilateral negotiations to agree on globally agreed-to law. That is not to say that the ATT has no normative value. Rather, the opposite. Substantively, it may be lacking on many fronts $^{51}$, but symbolically it has, like the League of Nations did, planted a global normative seed that is already growing and no doubt will continue to grow. It is evidence of a moral drive towards linking the arms trade, as one traditionally having both a commercial and security-based existence, with the value of the human life.

Even with signatures and ratifications, though, the preliminary value of the ATT has not been promising. The United Kingdom's lack of effective implementation and practice does question whether the moral consciousness of a state can ever overpower the capitalist overtures of priority markets, as in the case of the UK transfer of arms to Saudi Arabia. The national system must take steps to ensure that a simple signature and ratification must translate to integration within its domestic legal framework and comply with the obligations under the ATT. Even if knowledge of illicit trade is not definitively known by states before a transfer takes place, they must have regard for international humanitarian law, international criminal law and human rights and not transfer to actors where there is even the risk of unlawful arms conduct. There must be a high and strict application of due diligence by states in this regard. This means integrating a comprehensive and stringent risk assessment in their national control system, measures to cooperate with the importing state, as well as consequential measures if knowledge of prohibited acts is established after the authorisation of a transfer.

In the United Kingdom's case, the government should have implemented additional and supplementary national laws and policy in order to properly prevent arms transfers to those wishing to use them illicitly and reduce the risk of any ambiguity that the ATT may contain as to its obligations. This should include full and complete disclosure of UK arms transfers and investigations of beneficiary countries prior to any potential sales taking place. The United Kingdom must suspend arms transfers to countries that are using the same weapons to commit international law and human rights violations, such as ones evident in Yemen through the Saudi-led intervention. Increased diplomatic avenues should be utilised to prevent and halt conflicts, bringing the violators' actions back in line with the ATT obligations.

Given that the ATT came into force in December 2014, it may still be too early to predict its true impact on the nature of international arms sales, especially since the First Conference of States Parties only recently took place in Mexico to iron out pertinent administrative issues for the effective implementation of the treaty. The AT, however, does have the potential to have a significant impact beyond merely a symbolic nature. That is, if its contents are translated within the national control system in the way in which it was intended as 'objectively and indiscriminately', as opposed to states succumbing to the realpolitik and conquering the view that the ATT favours exporters, leaving less-developed countries without the capacity to ensure the adherence of its provisions.

${ }^{51}$ Given the valuable role of the ATT Secretariat, this may change in the coming years. 